\title{
The role of near-field interaction between seismic waves and slope on the triggering of a rockslide at Lorca (SE Spain)
}

\author{
P. Alfaro ${ }^{1}$, J. Delgado ${ }^{1}$, F. J. García-Tortosa ${ }^{2}$, J. J. Giner ${ }^{1}$, L. Lenti ${ }^{3}$, C. López-Casado ${ }^{4}$, S. Martino ${ }^{5}$, and \\ G. Scarascia Mugnozza ${ }^{5}$ \\ ${ }^{1}$ Dpt. Ciencias de la Tierra y del Medio Ambiente, Universidad de Alicante, Ap. Correos 99, 03080 Alicante, Spain \\ ${ }^{2}$ Dpt. Dpto. Geología, Universidad de Jaén, Campus Las Lagunillas, 23071 Jaén, Spain \\ ${ }^{3}$ Institut français des sciences et technologies des transports, de l'aménagement et des réseaux (IFSTTAR), \\ 58 Boulevard Lefebvre, 75732 Paris Cedex 15, France \\ ${ }^{4}$ Dpt. Física Teórica y del Cosmos, Facultad de Ciencias, Campus Fuentenueva, Universidad de Granada, \\ 18003 Granada, Spain \\ ${ }^{5}$ Dipartimento di Scienze della Terra, Università di Roma “Sapienza”, P.le. Moro 5, 00185 - Roma, Italy
}

Correspondence to: S. Martino (salvatore.martino@uniroma1.it)

Received: 12 April 2012 - Revised: 30 August 2012 - Accepted: 17 October 2012 - Published: 12 December 2012

\begin{abstract}
A $\sim 1000 \mathrm{~m}^{3}$ rockslide occurred close to Lorca (SE Spain) during the main shock $\left(M_{\mathrm{W}}=5.1\right)$ of the May 2011 seismic sequence. The location of the rockslide, within $10 \mathrm{~km}$ of the earthquake epicenter and along the southern slope of a valley in which similar geological conditions occur on both slopes of the valley, suggests a significant near-field effect due to local seismic response. This could be related to the specific interaction between the topography and the obliquely propagating seismic waves.

A dynamic stress strain numerical model was constructed using the FLAC 7.0 finite difference code to back analyze the Lorca rockslide event and relate its occurrence to both the local seismic amplification and the interaction between seismic waves and local topography. The results indicate that only for seismic waves with incidence angles in the range $0^{\circ}-50^{\circ}$ are the occurred slope instabilities expected. These results do not significantly change when varying the values for either stiffness or strength parameters within the range of the experimental data.
\end{abstract}

\section{Introduction}

Earthquake-induced landslides on both rock and soil slopes (Keefer, 1984; Hutchinson, 1987; Sassa, 1996; Rodriguez et al., 1999; Prestininzi and Romeo, 2000; Chigira et al., 2010) can result in significant damages (Bird and Bommer, 2004).
According to empirical correlations (Keefer, 1984; Sassa, 1996; Fukuoka et al., 1997; Rodriguez et al., 1999; Romeo, 2000), disrupted landslides, such as rockfalls and rockslides, can occur at maximum expected distances within 10 to $40 \mathrm{~km}$ for earthquake magnitudes in the range 5.0-6.0. These results were confirmed by a recent study that considered the instrumental period only (Delgado et al., 2011).

Nevertheless, the maximum distance of occurrence of landslides may significantly change as an effect of local site conditions (Gallipoli et al., 2000; Wasowsky and Del Gaudio, 2000; Havenith et al., 2002, 2003a, b; Martino and Scarascia Mugnozza, 2005; Meric et al., 2007; Bourdeau and Havenith, 2008; Bozzano et al., 2008; Bordoni et al., 2010; Bozzano et al., 2011b; Havenith et al., 2003a, b). In particular, seismically-induced disrupted landslides can be strongly influenced by the orientation of local discontinuities and the topographic amplification of the ground motion (Crawford and Curran, 1981; Ashford et al., 1997; Harp and Jibson, 2002; Moore et al., 2011; Lovati et al., 2011). The amplification effect has been confirmed by observations of anomalous concentrations of earthquake-induced rockslides (Sepulveda et al., 2005a, b). The amplification effect has also been supported by instrumental evidence obtained from ambient noise measurements of the maximum amplification of standing waves that are polarized perpendicular to opened systematic fractures (i.e. normal mode motion of the wavefield) 
resulting from slope movements in a rockslide area (Burjanek et al., 2012).

The evidences of effects of seismic amplification due to specific topography types, such as ridges and canyons, derive from numerical and instrumental studies (Sanchez-Sesma and Rosenblueth, 1979; Geli et al., 1988; Athanasopoulos et al., 1999; Zaslavsky and Shapira, 2000; Kamalian et al., 2008; Bakavoli and Hagshenhas, 2010), these last ones based on accelerometric data from middle to high magnitude earthquakes (i.e. 1909 Angot (France); 1976 Friuli (Italy); 1980 Irpinia (Italy); 1985 Chile). In particular, the effect of steplike slope topography (i.e. a sketched slope profile constituted of flat top and bottom and of a constant dip face) on seismic ground motions has been studied by using numerical modeling (Ashford and Sitar, 1997; Bouckovalas and Papadimitriou, 2005; Nguyen and Gatmiri, 2007; Papadimitriou and Chaloulos, 2010; Lenti and Martino, 2011), as reliable field measurements are difficult to obtain because wave scattering due to step-like slope geometries require an unrealistically dense distribution of recording stations. These studies have demonstrated that (i) step-like slope topographies may lead to intense amplification and de-amplification irregularly along the slope, depending on the slope geometry; and (ii) the possible interactions among the seismic input, the slope and preexisting landslide masses depend on seismic properties such as frequency content, directivity and the peak of ground acceleration (Bozzano et al., 2008, 2011a, b; Martino and Scarascia Mugnozza, 2005; Del Gaudio and Wasowsky, 2010; Lenti and Martino, 2011).

Given these considerations, the role of the direction of seismic waves propagating in the near-field needs further study. To this aim, the incidence angle of the wavefield, i.e. measured between the direction of propagation of the seismic wave front and the normal of the horizontal plane, represents a key parameter, as proved by theoretical studies based on numerical modeling (Sanchez-Sesma and Rosenblueth, 1979; Ashford and Sitar, 1997). These studies demonstrated that more asymmetric and intense amplification functions are caused by increasing incidence angles of seismic waves in relation to topographic features such as ridges and canyons. Nevertheless, no specific studies based on real examples have so far evaluated the possible role of the seismic wave incidence angle on the earthquake-triggering of landslides. It is worth noting that specific features of such case histories should be (i) a well documented landslide occurrence, (ii) a near-field landslide trigger, and (iii) the availability of accelerometric records of the triggering earthquake close to the landslide site.

Considering this, using the rockslide (according to the definitions by Hungr et al., 2001) that occurred close to Lorca (in SE Spain) as an effect of the mainshock of May 2011 $\left(M_{\mathrm{w}}=5.1\right)$, it is possible to analyze, via numerical modeling, the triggering conditions related to the interaction between the seismic input and the slope failure. This analysis may reveal a possible dependence of the landslide-triggering

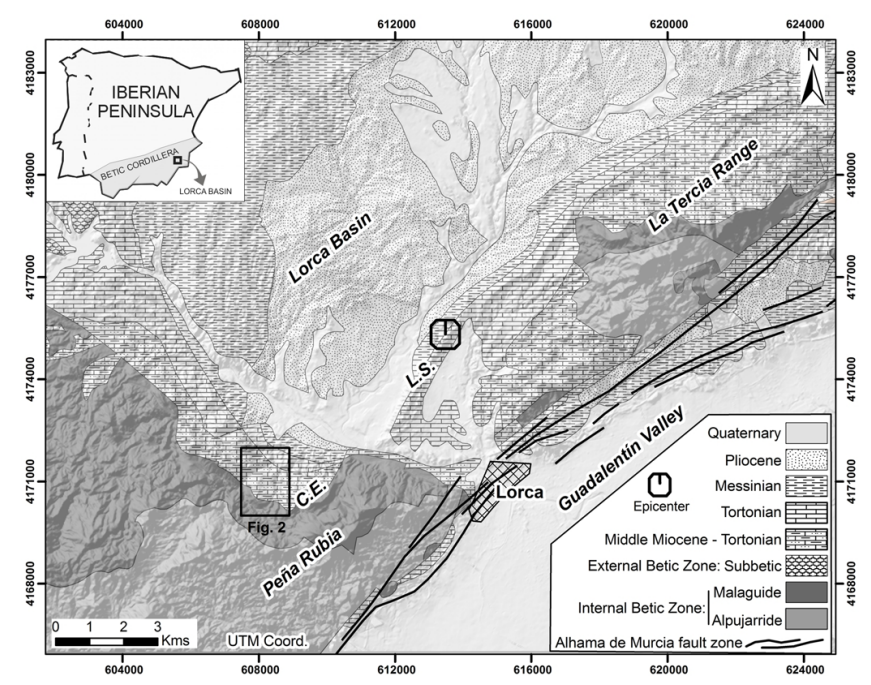

Fig. 1. Location map of the study zone. Location of Fig. 2 is also shown.

from the seismic wave propagation and the local seismic amplification.

More specifically, the aim of the modeling performed here is to "back analyze" a landslide event for which there is no completely known destabilizing action, since, due to the near-field conditions, there is uncertainty related to the incidence angle of the seismic waves. For this reason, the proposed approach needs a site-specific and well-constrained engineering-geological model of the landslide slope, i.e. a model supported by in situ surveys and investigations. To test the dependence of the rockslide triggering on the incidence angle of the seismic waves, a "sensitivity analysis" was performed by assuming different values of the incident angles. The "validation process" consisted in comparing the obtained results with the location and size of the unstable areas that resulted from the modeling and those observed in the field. Moreover, a "parametric analysis" was performed to provide more robust results, making it possible to evaluate the weight of the errors related to the attributed values of the mechanical parameters.

In the following, the evidences of the in situ surveys and investigations are first of all reported and the engineeringgeology model of the collapsed slope is derived. The considered seismic actions are illustrated and the numerical modeling is introduced and discussed according to the above described methodological approach.

\section{The Lorca rockslide}

\subsection{Geological setting}

The study area is located in the eastern zone of the Betic Cordillera (Fig. 1). It is part of the so-called Lorca Basin, a Neogene-Quaternary basin (Montenat et al., 1990) located 
next to the Eastern Betic Shear Zone, a $\approx 450 \mathrm{~km}$ leftlateral tectonic corridor that extends from Almería to Alicante (Bousquet, 1979; De Larouzière et al., 1988; Silva et al., 1993). The Alhama de Murcia Fault, which is the fault most likely activated in the 2011 Lorca earthquake (Cabañas et al., 2011), is located at the SE border of this basin.

The Lorca Basin has developed along the boundary between the Internal and External Betic Zones. The basin fill deposits, more than $1500 \mathrm{~m}$ thick in the central parts of the basin (Wrobel et al., 1999), are attributed to Middle-Late Miocene and Pliocene epochs. The rockslide under investigation is located in the SW part of the basin, in a zone also known as "Rambla de los diecisiete ojos", next to the Sierra de Peña Rubia, a basement outcrop consisting of sedimentary and metamorphic rocks of the Alpujarride and Malaguide domains. The rocks of the Betic Internal Zone are unconformably covered by Miocene bioclastic limestones, sandstones (calcarenites) and marls (Montenat et al., 1990). From a stratigraphic point of view, the studied rockslide involves a Tortonian succession with frequent lateral facies changes (Wrobel et al., 1999). The "Rambla de los diecisiete ojos" zone is characterized by a calcarenitic unit with reefal carbonates that overlay marls (Fig. 2).

The Miocene and Pliocene basin fill deposits are deformed and uplifted by recent and active folding and faulting. Although the study area is on the border of the Lorca basin, where deformation is typically more intense than in the central region, the Tortonian strata considered here are nearly horizontal (Fig. 2).

The recent erosion of these sedimentary rocks has created characteristic ridges and cliffs within the calcarenitic unit. A narrow one- to two-meter-deep cut has developed along the base of the cliff.

The rockslide affected the calcarenitic unit and is located in the southern slope of the valley (Fig. 3). It consisted of two separate areas of instabilities of approximately 700 and $300 \mathrm{~m}^{3}$. As movement progressed, the rockslide transformed into a rock avalanche, whose individual rock blocks reached the bottom of the valley and ran up the opposite slope. Along the north slope of the valley, two small instabilities were triggered by the earthquake and affected the same calcarenitic unit (Figs. 2 and 3).

\subsection{Geomechanical properties of the involved rock masses}

The materials found in the study zone were characterized by in situ geomechanical surveys. Joint properties were measured along scanlines, following the procedures described by the ISRM (1978). The Geological Strength Index, which is needed for applying the Hoek-Brown failure criterion (Hoek et al., 2002), was determined following the procedure described by Marinos et al. (2005). Additionally, several intact rock block samples were taken and tested in the laboratory. From these samples, up to 20 cylindrical calcarenitic cores
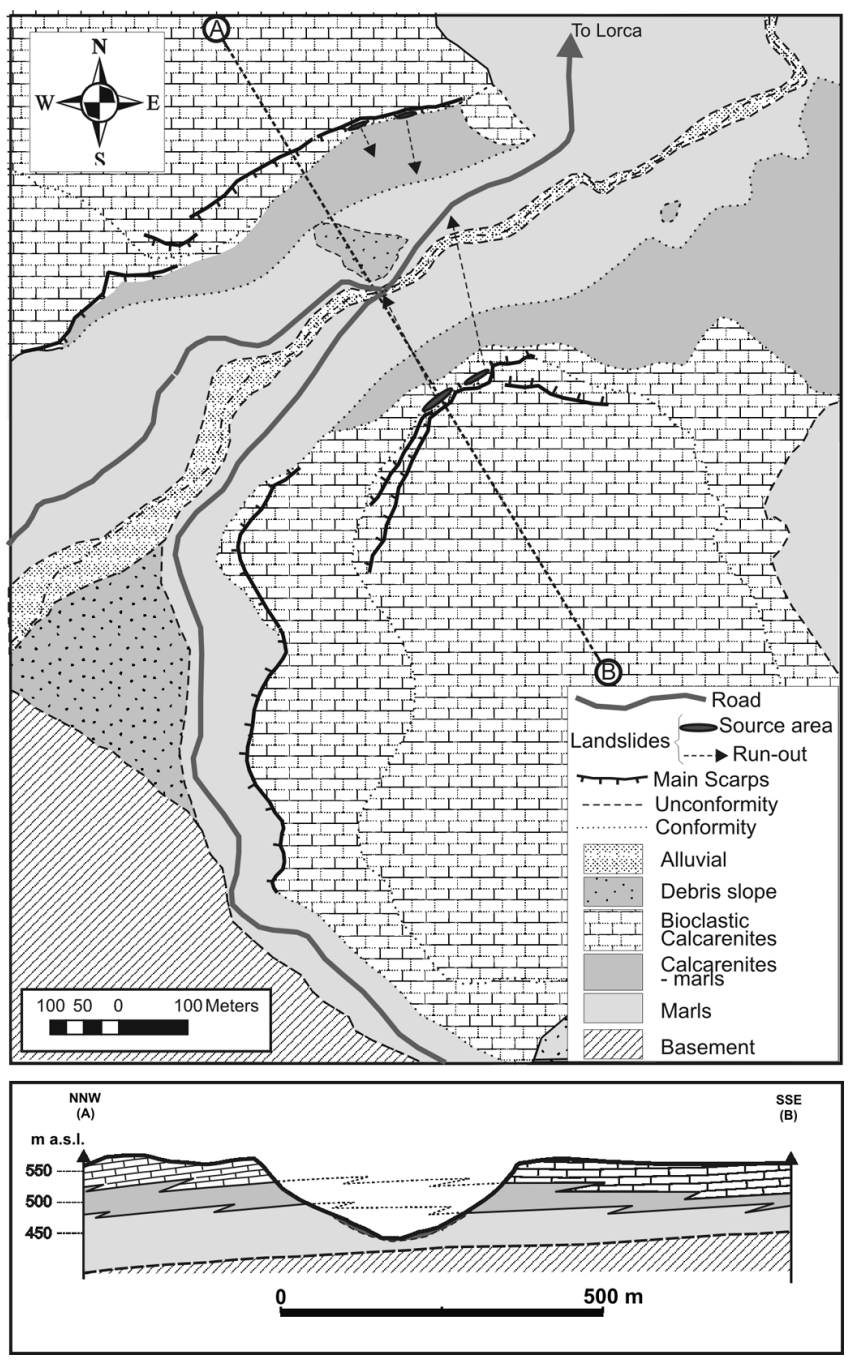

Fig. 2. Geological map and geological cross-section of the "Rambla de los diecisiete ojos" zone.

were drilled and then tested to determine uniaxial compression strength (UCS) and elastic moduli. For the marls unit, 10 samples were point load tested to estimate the corresponding UCS.

Based on the in situ geomechanical scanlines, three main joint sets were recognized in both calcarenites and marls outcropping along the considered slope. These include a low angle joint set (angle of dip of approximately $20^{\circ}$ ) related to bedding (Table 1). More specifically, two high angle joint sets (with a dip greater than $70^{\circ}$ ) involve the calcarenites, whereas only a high angle joint set involves the marls and is coupled with a low angle joint set so that it can be distinguished with respect to bedding.

To find the main anisotropy of the rock masses due to secondary joints characterized by the higher angles of dip (excluding the strata characterized by a low dip attitude), the intersection line between the observed joint planes not related 

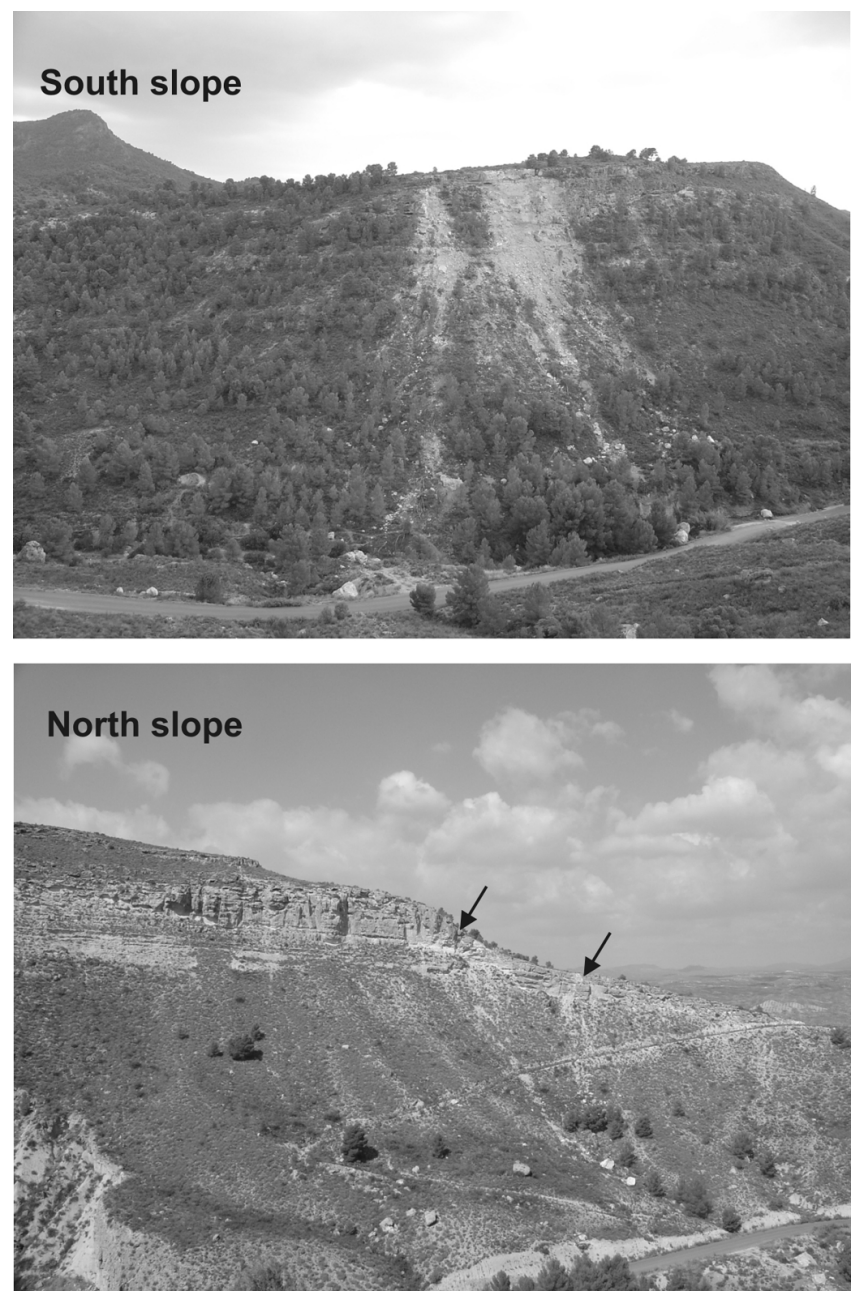

Fig. 3. Views of the studied slopes. Top: Southern slope (large failures); bottom: Northern slope (small failures are shown by the arrows).

to the strata was derived with a stereographic plot on the lower hemisphere of the Schmidt net (Table 1). The resulting intersection lines were posted along the cross-section by considering the apparent inclination derived by examining the angle between the intersection line of the joint planes and the direction of the geological cross section. A SE dipping intersection line with an apparent inclination higher than $70^{\circ}$ was observed for the calcarenites, while a SE dipping intersection line with an apparent inclination lower than $40^{\circ}$ was observed for the underlying marls.

To derive the rock mass strength parameters, two different approaches were used for attributing stiffness and strength parameters to the rock mass and to the intersection lines of the secondary joint planes along the considered cross section. The Hoek-Brown approach (Hoek et al., 2002) was used to attribute an equivalent strength to the rock mass by assuming the characteristic parameters reported in Table 2, whereas to attribute the values of the strength parameters to
Table 1. Geomechanical properties derived from in situ measurements for the joint sets.

\begin{tabular}{lcrrr}
\hline \multirow{4}{*}{ Calcarenites } & $\begin{array}{c}\text { joint } \\
\text { set }\end{array}$ & $\begin{array}{r}\text { azimuthal dip } \\
\text { direction }\left({ }^{\circ}\right)\end{array}$ & $\begin{array}{r}\text { dip } \\
\left({ }^{\circ}\right)\end{array}$ & $\begin{array}{r}\text { apparent } \\
\text { dip }\left(^{\circ}\right)\end{array}$ \\
\hline \multirow{4}{*}{ Marls } & strata & 70 & 20 & 3 \\
& $j 1$ & 255 & 78 & 47 \\
& $j 2$ & 185 & 78 & 75 \\
& intersection line $j 1-j 2$ & 221 & 76 & 55 \\
\hline & strata & 70 & 20 & 3 \\
$j 1$ & 250 & 85 & 62 \\
& $j 2$ & 110 & 35 & 15 \\
& intersection line $j 1-j 2$ & 162 & 25 & 15 \\
\hline
\end{tabular}

the intersection lines of the secondary joint planes, a negligible cohesion was assumed and an effective friction angle was computed according to the Barton criterion (i.e. considering both the roughness and the UCS of the joint planes measured on the outcropping rock masses) (Barton and Bandis, 1990).

\subsection{Geophysical measurements}

Determination of shear velocities of involved materials was done through ReMi technique (Louie, 2001) that provides an effective and efficient way to estimate the rock mass characteristic along a linear array, where the setup length is determined by the desired depth of investigation. For this purpose, three profiles were done, one on each relevant lithology (marls, calcarenites and quartzites). The geophone spacing was $4 \mathrm{~m}$ for the first profile and $2 \mathrm{~m}$ for the other two profiles. Vertical 1-D S-wave velocities profiles were obtained through the SeisOpt ReMi software package (Optim, 2003). To reduce uncertainties inherent to this technique (the inversion is non-unique), seismic refraction profiles were also collected along the same profiles and a simple model for each profile was obtained. Thicknesses retrieved from these models were then employed for obtaining the 1-D S-wave profiles. The results are shown in Fig. 4

There is a weathered layer at the ground surface in all cases, characterized by very low S-wave velocities (approximately $200 \mathrm{~m} \mathrm{~s}^{-1}$ ) that increase with depth (abruptly in the case of the calcarenites unit and more progressively for the marls).

\section{The triggering earthquake}

\subsection{The 11 May 2011 Lorca earthquake}

The earthquake under consideration is the main event in a seismic series that started at 15:05 (GMT) when the first foreshock occurred, which was the main foreshock among those recorded $\left(M_{\mathrm{w}}=4.5\right)$. At 16:47 (GMT), the main event $\left(M_{\mathrm{w}}=5.1\right)$ struck the zone, causing notable damage to the city of Lorca and nearby localities ( $I_{\max }=$ VII EMS scale), including many injuries and 9 deaths. After this event, more 
Table 2. Values assumed for the jointed rock masses according to the Hoek and Brown (2002) approach.

\begin{tabular}{lrrrrrrrrrrrr}
\hline & $\begin{array}{r}\sigma_{c i} \\
(\mathrm{MPa})\end{array}$ & $m_{i}$ & $D$ & RMR & GSI & $m_{b}$ & & $s$ & & Jv & $\begin{array}{r}c \\
(\mathrm{MPa})\end{array}$ & $\begin{array}{r}\phi t \\
(\mathrm{MPa})\end{array}$ \\
\hline calcarenites & $25-32$ & $12-15$ & 0.7 & $65-75$ & $60-70$ & $1.333-2.885$ & $0.003-0.013$ & $0.503-0.501$ & 0.8 & $0.39-0.79$ & $40-47$ & $0.057-0.143$ \\
marls & $13-19$ & 7 & 0.7 & $45-55$ & $40-50$ & $0.259-0.448$ & $0.00017-0.00071$ & $0.511-0.506$ & 74 & $0.09-0.20$ & $23-29$ & $0.0084-0.030$ \\
\hline
\end{tabular}

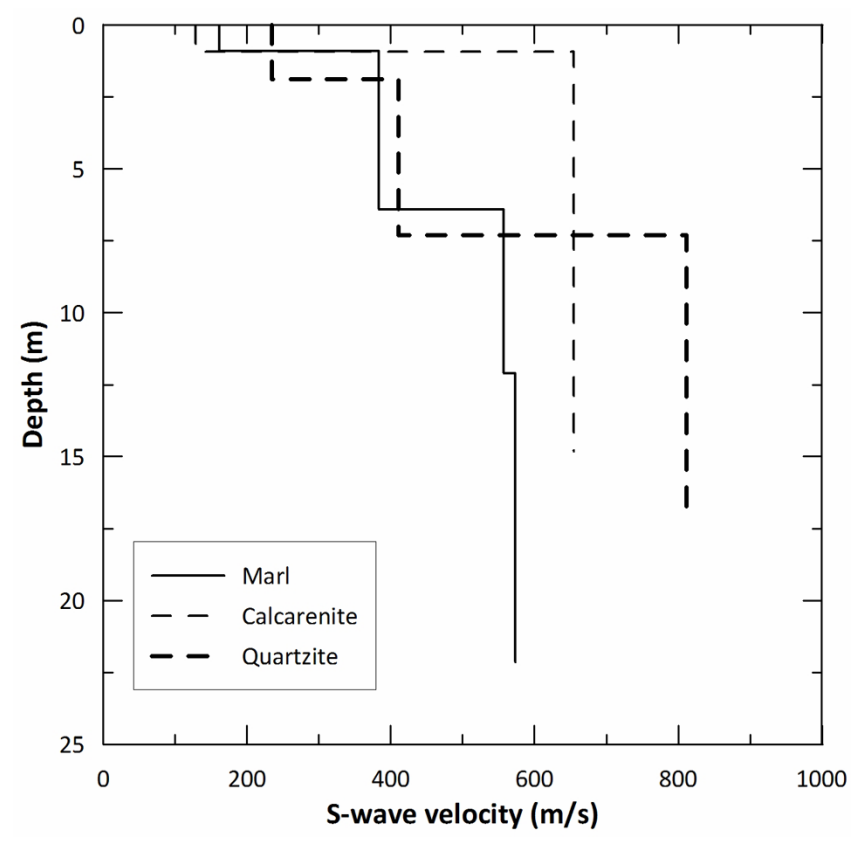

Fig. 4. 1-D S-wave profiles obtained for marly, calcarenitic and quartzite.

than 150 aftershocks were recorded. The events of this series were characterized by shallow foci, with the majority located between 1 and $6 \mathrm{~km}$, with a depth of $3 \mathrm{~km}$ for the mainshock (Cabañas et al., 2011).

Ground motion was recorded by dozens of stations belonging to several agencies. The focal mechanism for the main event is consistent with strike-slip motion with some reverse component, according to the characteristics of the Alhama de Murcia fault in this sector (Cabañas et al., 2011).

The Spanish Strong Ground Motion Network, operated by the IGN, recorded the main event of the series at 17 sites, with epicentral distances ranging from 3 to $185 \mathrm{~km}$. The peak ground motion values ranged from $0.36 \mathrm{~g}$ for the Lorca's station ( $3 \mathrm{~km}$ from epicenter) to $0.002 \mathrm{~g}$ for the more distant stations (Cabañas et al., 2011).

\subsection{Triggering input from the recorded accelerograms}

To derive a seismic input for the numerical models used in analyzing the Lorca rockslide earthquake trigger, (i.e. corresponding to about $8 \mathrm{~km}$ distance from the epicenter accelerometric record), a spectral attenuation was specifically processed. This was used because no attenuation law could be regarded as reliable for the studied area (Alfaro et al., 2012). With this aim, five accelerometric records of 11 May 2011 for the Lorca earthquake mainshock were considered, as recorded by the stations ALM, ZAR, VLR, CIE and OLU of the Spanish Strong Ground Motion Network, with distances from the epicenter up to $100 \mathrm{~km}$ and azimuthal locations between $313^{\circ}$ and $16^{\circ}$ (Table 3 ). It is worth noting that the record available from the Lorca (LRC) accelerometric station was excluded because it amplified in the range $1.5-3 \mathrm{~Hz}$ for the $\mathrm{N}-\mathrm{S}$ component and in the range $1.5-2 \mathrm{~Hz}$ for the W-E component, as discussed by Alfaro et al. (2012).

For these cases, only the horizontal components of the ground motion were considered. Starting from the Fourier spectra of the available accelerometric records, 14 selected values of the Fast Fourier Transform (FFT), corresponding to selected frequency bands within the range $0-20 \mathrm{~Hz}$, were considered versus the epicentral distance and correlated by exponential functions (Table 4) with an $R^{2}$ higher than 0.6.

For each considered frequency, the FFT values computed by the correlation functions at $8 \mathrm{~km}$ from the earthquake epicenter were selected and interpolated to derive a time history (by performing the Fast Fourier Anti-Transform); with this aim, the phase spectrum of the accelerometric record at ZAR station (the closest one with respect to the Lorca rockslide site) was considered.

The accelerometric record derived in this way (Fig. 5a) was compared with the PGA versus distance (Fig. 6a), as well as with the PGA vs. Arias intensity (Fig. 6b) distributions obtained for all the considered accelerometric stations. The characteristic period $T_{m}$ (Bray and Rathje, 1998) of the resulting input was also computed (Fig. 6c) to verify the compatibility of the main frequency content of the input derived for the landslide site with respect to the recorded ones. The comparison demonstrated that the computed seismic input can be regarded as representative for the horizontal ground motion at $8 \mathrm{~km}$ from the earthquake epicenter and within the considered azimuthal range.

\section{Numerical modeling of seismic wave-slope interaction}

To evaluate the local seismic response along the geological cross-section of Fig. 2, a dynamic numerical modeling was performed using the FLAC 7.0 code (Itasca, 2011). The methodology employed during the numerical modeling is the same used by Lenti and Martino (2012) both to implement 
Table 3. Accelerometric station of the Spanish Strong Ground Motion Network.

\begin{tabular}{llrrrr}
\hline Station & Locality & $\begin{array}{r}\text { Epicentral } \\
\text { distance }(\mathrm{km})\end{array}$ & $\begin{array}{r}\text { azimuth } \\
\left({ }^{\circ}\right)\end{array}$ & Latitude & Longitude \\
\hline LOR & Lorca & 3.8 & 294 & $37^{\circ} 40^{\prime} 36^{\prime \prime} \mathrm{N}$ & $01^{\circ} 42^{\prime} 01^{\prime \prime} \mathrm{W}$ \\
ZAR & Zarcilla de Ramos & 25 & 313 & $37^{\circ} 50^{\prime} 40^{\prime \prime} \mathrm{N}$ & $01^{\circ} 52^{\prime} 40^{\prime \prime} \mathrm{W}$ \\
ALM & Alhama de Murcia & 26 & 40 & $37^{\circ} 50^{\prime} 30^{\prime \prime} \mathrm{N}$ & $01^{\circ} 26^{\prime} 04^{\prime \prime} \mathrm{W}$ \\
VLR & Velez-Rubio & 36 & 268 & $37^{\circ} 38^{\prime} 54^{\prime \prime} \mathrm{N}$ & $02^{\circ} 04^{\prime} 28^{\prime \prime} \mathrm{W}$ \\
CIE & Cieza & 63 & 16 & $38^{\circ} 14^{\prime} 11^{\prime \prime} \mathrm{N}$ & $01^{\circ} 25^{\prime} 05^{\prime \prime} \mathrm{W}$ \\
OLU & Olula del Rio & 67 & 241 & $37^{\circ} 21^{\prime} 13^{\prime \prime} \mathrm{N}$ & $02^{\circ} 17^{\prime} 50^{\prime \prime} \mathrm{W}$ \\
\hline
\end{tabular}

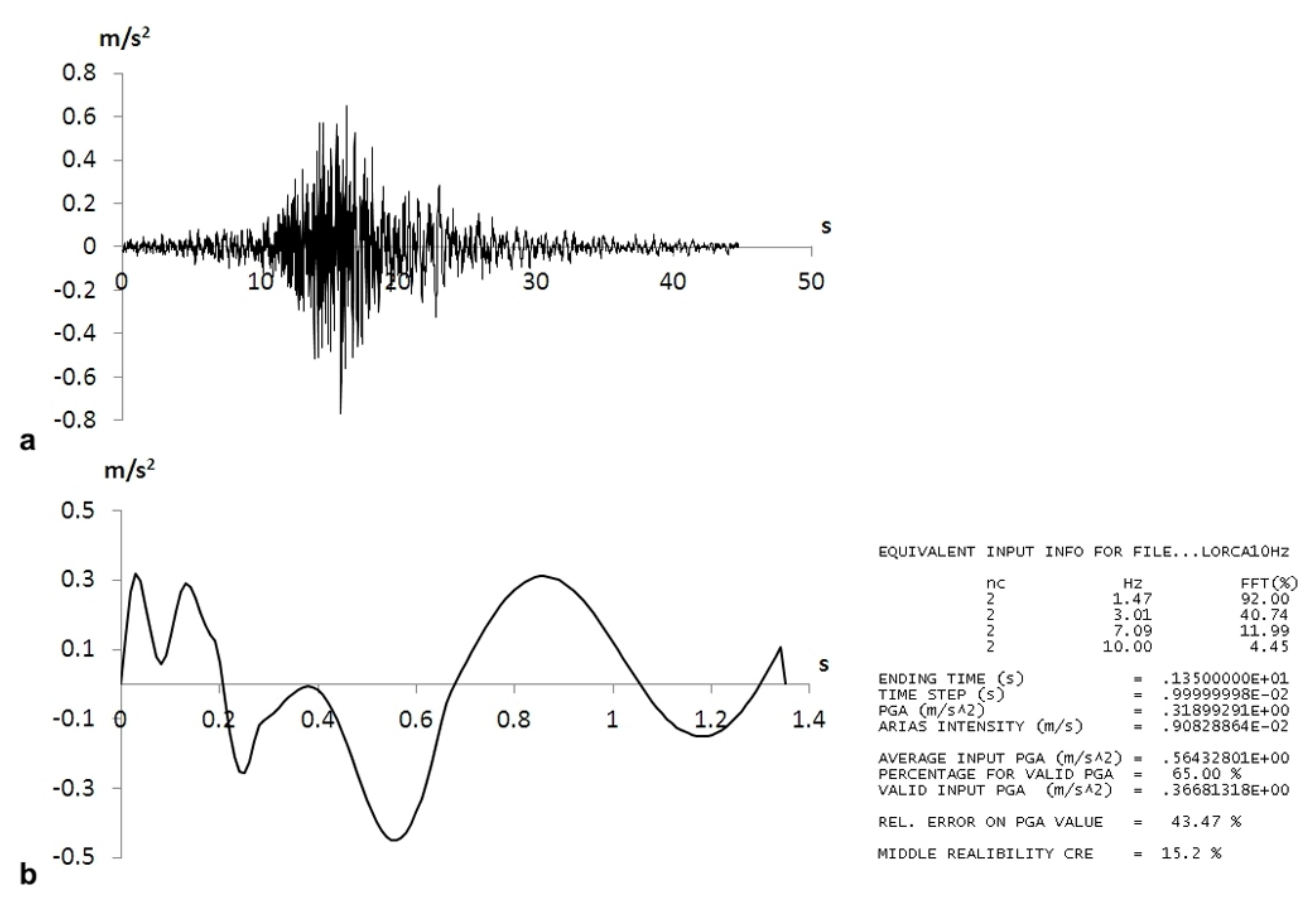

Fig. 5. (a) Accelerometric record for the seismic input derived for the rockslide site, $8 \mathrm{~km}$ from the epicenter of the Lorca earthquake; (b) Accelerometric time series for the LEMA_DES dynamic equivalent signal and related final report (Lenti and Martino, 2010) obtained for the seismic input referred to the rockslide site, $8 \mathrm{~km}$ from the epicenter of the 11 May 2011 mainshock of the Lorca seismic sequence.

the stress-strain simulation under dynamic conditions and to derive the amplification functions $A(f)$, the induced displacements and the plasticity state within the model. The physical and mechanical parameters of the considered soils are reported in Table 1, but for this preliminary analysis of local seismic response, they are attributed according to a viscoelastic constitutive law.

The numerical models were constructed by adopting geometrical conditions capable to guarantee a corresponding maximum admissible frequency for the model equal to $15 \mathrm{~Hz}$ (Kuhlemeyer and Lysmer, 1973). Energy dissipation was computed using a Rayleigh damping function (Zienkiewicz, 2005; Semblat and Pecker, 2009) by assuming a value of the minimum damping, $\xi_{\min }$, varied as a function of the shear strain according to the adopted dynamic behavior of the soil. This function guarantees that at each shear strain level, the maximum damping coefficient varies from $0.01-0.02$ within the frequency range of interest $(0-15 \mathrm{~Hz})$. Moreover, "quiet" boundary conditions were applied both at the base and at the lateral boundaries of the mesh.

For each slope configuration, an initial geostatic stress field was computed assuming an oblique gravitational field, (i.e. the gravity with respect to the rotated topographic surface of the models was here considered).

Different incidence angles (from $0^{\circ}$ to $70^{\circ}$ ) of the seismic wave front were considered because the rockslide was triggered in near-field conditions (i.e. at approximately $8 \mathrm{~km}$ from the epicenter). Thus, the modeled slope geometry was "rotated" to obtain the various incidence angles with respect to the seismic waves, and the seismic inputs were applied in the form of a vertical upward-propagating SV stress-wave. No negative angles (i.e. computed clockwise with respect to 
Table 4. Exponential correlation functions and related $R^{2}$ values referred to the FFT amplitude vs. epicentral distances derived from the accelerometric records of the 11 May 2011 mainshock of the Lorca seismic sequence.

\begin{tabular}{lll}
\hline $\mathrm{Hz}$ & $\begin{array}{l}\text { FFT amplitude } \\
\left(a-\mathrm{m} \mathrm{s}^{-1}\right) \mathrm{vs} .\end{array}$ & $R^{2}$ \\
& $\begin{array}{l}\text { epicentral distance } \\
(b-\mathrm{km})\end{array}$ \\
\hline 0.5 & $a=0.0532 e^{-0.043 b}$ & 0.968 \\
1 & $a=0.3055 e^{-0.070 b}$ & 0.861 \\
1.5 & $a=0.3336 e^{-0.065 b}$ & 0.612 \\
2 & $a=0.1913 e^{-0.047 b}$ & 0.994 \\
3 & $a=0.2199 e^{-0.055 b}$ & 0.938 \\
4 & $a=0.1778 e^{-0.060 b}$ & 0.864 \\
5 & $a=0.0693 e^{-0.045 b}$ & 0.606 \\
6 & $a=0.1025 e^{-0.051 b}$ & 0.816 \\
7 & $a=0.1980 e^{-0.061 b}$ & 0.984 \\
8 & $a=0.0778 e^{-0.048 b}$ & 0.915 \\
9 & $a=0.0620 e^{-0.052 b}$ & 0.891 \\
10 & $a=0.1594 e^{-0.073 b}$ & 0.913 \\
15 & $a=0.2454 e^{-0.083 b}$ & 0.677 \\
20 & $a=0.0291 e^{-0.085 b}$ & 0.994 \\
\hline
\end{tabular}

vertical) were considered because the earthquake epicenter was located SE of the considered geological cross-section.

To evaluate the seismic amplification due to the slope configurations, a delta-like Gabor function $(G(t))$ was applied in the form of a vertical upward SV stress-wave. The choice of the Gabor function parameters ensures negligible spectral amplitudes of the resulting signal for frequencies higher than $10 \mathrm{~Hz}$. To avoid numerical errors during dynamic calculation, the function has a symmetrical shape and a null integral over the total time.

The results demonstrate that the $A(f)$ functions change significantly with the incidence angle of the seismic wave front (Fig. 7). Moreover, with increasing incidence angles, the maximum values of the amplification function $A(f)$ (i.e. up to 2) shifts position from the southern slope of the valley (where the rockslide occurred) towards the northern slope. In the case of normal incidence (i.e. far-field conditions), the modeled $A(f)$ function shows maximum values at approximately $1 \mathrm{~Hz}$ throughout the calcarenitic plateau as well as immediately behind the top of the southern slope (here in the range $3-7 \mathrm{~Hz}$ ). However, for the non-normal incidence angles, the maximum values of the $A(f)$ function results in the frequency range $1-3 \mathrm{~Hz}$ only along the valley slopes with a location varying from the left to the right slope at decreasing incidence angles.

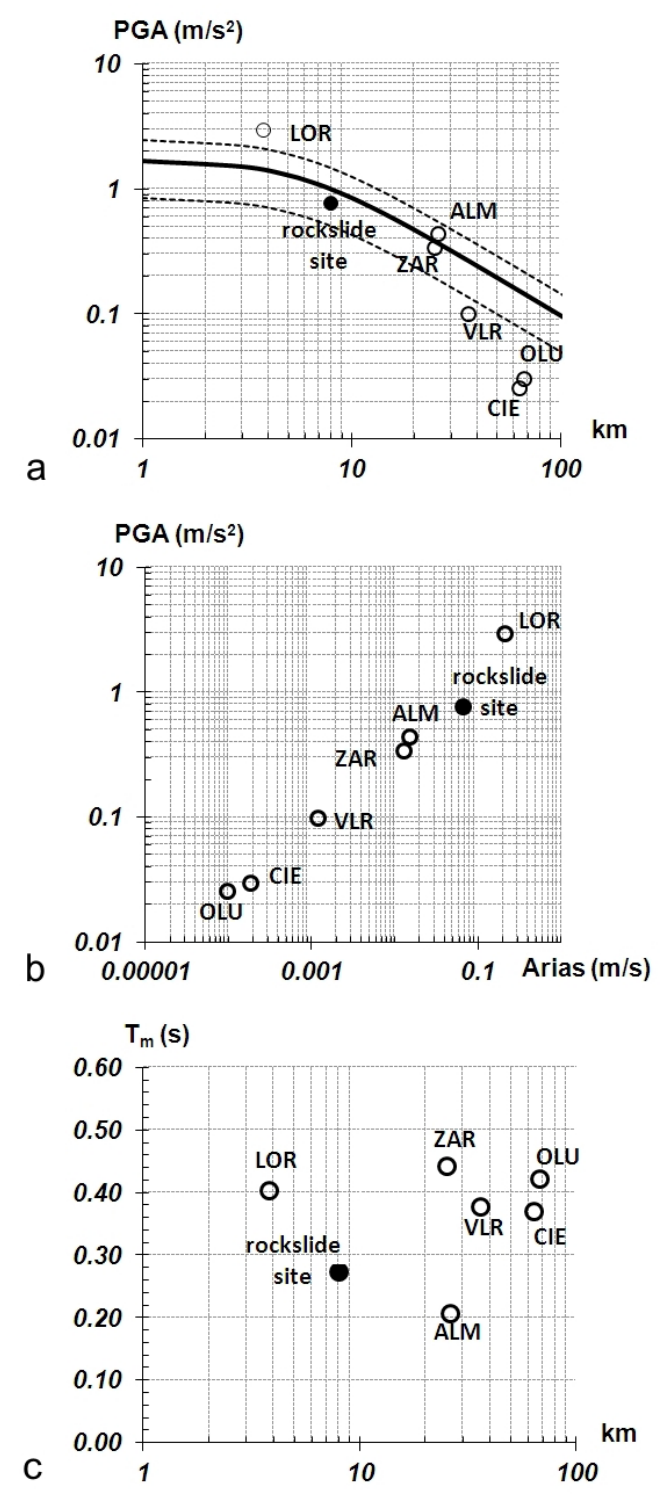

Fig. 6. (a) PGA vs. epicentral distance compared with the Italian Sabetta and Pugliese (1987) attenuation law (black and dashed lines); (b) PGA vs. Arias intensity; (c) Tm vs. epicentral distance for the records of the 11 May 2011 mainshock of the Lorca seismic sequence, recorded at the various accelerometric stations (empty symbols) and for the seismic input referred to the rockslide site, $8 \mathrm{~km}$ from the main shock epicenter (full symbol).

\section{Dynamic slope stability analysis}

To back analyze the slope failure that occurred at "Rambla de los diecisiete ojos" via stress-strain dynamic numerical modeling through the FLAC 7.0 FDM code, a generalized rheological model was assumed to simulate non-linear instable conditions (i.e. out of the non-linear stable strain range) of the involved rock masses. 

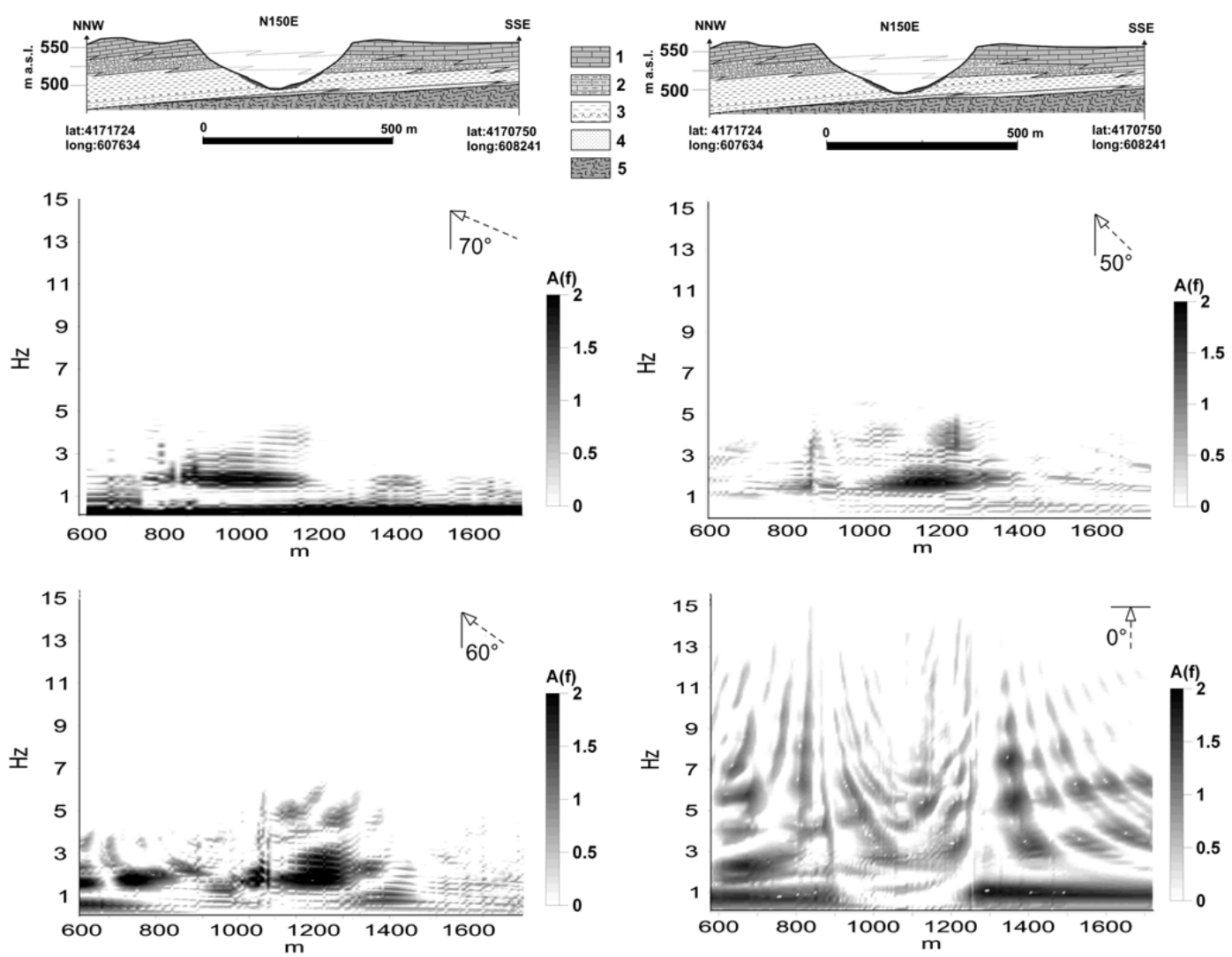

Fig. 7. $A(f)$ functions obtained by the 2-D numerical modeling of the seismic wave propagation with different incidence angles (i.e. $0^{\circ}$, $50^{\circ} .60^{\circ}$ and $70^{\circ}$, respectively). Legend: (1) Calcarenites; (2) Calcarenites-marls; (3) Marls with gypsum levels to the base; (4) Sands and conglomerates; (5) Triassic basement.

According to some authors (Cetin et al., 2004; Zhai et al., 2004), the non-linear instable dynamic behavior was modeled, considering more conservative perfectly plastic conditions controlled by Mohr-Coulomb yield criterion implemented for an ubiquitous joint solution (Itasca, 2011); that is, by assuming that the limit state conditions can be related to the strength properties of both the rock mass and the intersection line along the considered cross-sections of the main joint sets. Therefore, in this work only high angle joint sets were considered to derive the angle of inclination of the intersection line; the low-angle joints related to the strata were not considered.

When plastic failure occurred during the modeling, stiffness parameters of both the calcarenites and the marls were reduced up to one order of magnitude and up to half an order of magnitude, respectively (Maffei et al., 2005; Bozzano et al., 2011a). At the same time, if yielding conditions were reached, "residual values" (i.e. reliable for large deformations) were attributed to the strength parameters; for the joints these residual values were computed according to the Barton criterion (Barton and Badis, 1990).

The parameter values attributed to the numerical models (Table 5) were derived based on in situ and laboratory tests: (a) the Hoek-Brown approach (Hoek et al., 2002) for strength parameters; (b) the Barton criterion for joint strength (i.e. based on JCS, JRC measured by the geomechanical scanlines); and c) theoretical relationships among seismic wave velocities $\left(V_{\mathrm{p}}\right.$ and $\left.V_{\mathrm{s}}\right)$ derived from the ReMi investigations and the dynamic stiffness of the rock masses.

Starting from the accelerometric records which were derived for the $8 \mathrm{~km}$ epicentral distance, leveled energy, multifrequency, dynamic equivalent signals were derived (Fig. 5b) according to the LEMA_DES approach by Lenti and Martino (2010). The LEMA_DES procedure enables control of the frequency and energy content of the equivalent inputs, making it possible to do the following: (i) check that the frequency content of the derived signals is defined within a representative/admissible range; (ii) avoid exceeding the upper-threshold frequency during modeling; (iii) narrow the energy gap between real and simulated seismic actions; (iv) control the maximum intensity of the adopted action; and (v) consider seismically-induced effects arising from frequency combinations, that is from dynamic and not cyclic actions.

In particular, the LEMA_DES procedure generates a sequence of functions and signals that accomplish the 
Table 5. Values of geomechanical parameters assumed for the FLAC dynamic numerical modeling. $v$ - Poisson coefficient; $E$ - Young modulus; $K$ - Bulk modulus; $G$ - shear modulus; $V_{\mathrm{S}}-\mathrm{S}$-wave velocity; $V_{\mathrm{p}}$ - P-wave velocity; fr - friction angle; coh - cohesion; ten tensile strength; $j_{\text {ang }}-$ joint angle; $j_{\text {fr }}$ - joint friction angle; $j_{\text {coh }}-$ joint cohesion.

\begin{tabular}{|c|c|c|c|c|c|c|c|c|c|c|c|c|c|c|}
\hline & constitutive law & $\begin{array}{r}\operatorname{den}^{\mathrm{d}} \\
\mathrm{kg} \mathrm{m}^{-3}\end{array}$ & $v$ & $\begin{array}{r}E \\
\mathrm{~Pa}\end{array}$ & $\begin{array}{c}K \\
\mathrm{~Pa}\end{array}$ & $\begin{array}{c}G \\
\mathrm{~Pa}\end{array}$ & $\begin{array}{r}V_{\mathrm{s}}^{\mathrm{a}} \\
\mathrm{ms}^{-1}\end{array}$ & $\begin{array}{r}V_{\mathrm{p}}^{\mathrm{a}} \\
\mathrm{m} \mathrm{s}^{-1}\end{array}$ & $\begin{array}{r}\mathrm{fr}^{\mathrm{b}} \\
0\end{array}$ & $\begin{array}{r}\mathrm{coh}^{\mathrm{b}} \\
\mathrm{Pa}\end{array}$ & $\begin{array}{r}\text { ten }^{\mathrm{b}} \\
\mathrm{Pa}\end{array}$ & $j_{\text {ang }}{ }^{\mathrm{c}}$ & $\begin{array}{r}j_{\mathrm{fr}}{ }^{\mathrm{c}} \\
\text { 。 }\end{array}$ & $\begin{array}{r}j_{\mathrm{coh}^{\mathrm{c}}} \\
\mathrm{Pa}\end{array}$ \\
\hline Calcarenites & ubiquitous joint & 2485 & 0.40 & $2.98 \times 10^{9}$ & $4.94 \times 10^{9}$ & $1.07 \times 10^{9}$ & 655 & 1600 & 46 & $5.90 \times 10^{5}$ & $9.15 \times 10^{4}$ & 76 & 68 & 0 \\
\hline Marls & mohr coulomb & 1980 & 0.47 & $1.79 \times 10^{9}$ & $9.66 \times 10^{9}$ & $6.10 \times 10^{8}$ & 555 & 2300 & 26 & $1.40 \times 10^{5}$ & $1.60 \times 10^{4}$ & 25 & 48 & 0 \\
\hline Triassic basement & elastic & 2578 & 0.44 & $4.74 \times 10^{9}$ & $1.26 \times 10^{10}$ & $1.65 \times 10^{9}$ & 800 & 2400 & - & - & - & - & - & - \\
\hline
\end{tabular}

Data source: ${ }^{\mathrm{a}}$ REMI; ${ }^{\mathrm{b}}$ Hoek and Brown; ${ }^{\mathrm{c}}$ geomechanical scanlines, ${ }^{\mathrm{d}}$ laboratory.

following: (1) provide the selection of characteristic frequencies from a smoothed Fourier spectrum of a reference accelerogram; (2) achieve a null integral over the entire duration of the final signal and a spectral density negligible at frequencies lower than the minimum characteristic one; and (3) generate a resulting multi-frequency dynamic equivalent signal, which is energy-equivalent to the reference signal, best fitted in terms of PGA via an iterative procedure performed on the number of equivalent cycles and whose time duration is significantly shorter than the reference.

To test the role of the incidence angle of the seismic waves on the rockslide trigger, a "sensitivity analysis" was performed by assuming different values within the range $0^{\circ}-$ $90^{\circ}$, i.e. from theoretically far-field conditions to theoretically near-fault conditions.

The resulting stress-strain numerical outputs (total displacements and sheared zones - Figs. 8 to 10) demonstrate that failure conditions generally occur for all the considered incidence angles of the seismic waves. Nevertheless, the affected volumes, failure mechanisms and the failure location significantly change with varying incidence angle. In particular, for the case of $50^{\circ}$ and $0^{\circ}$ incidence angles, a very important earthquake-triggered slope instability affects the southern slope of the valley (that is, where the rockslide actually occurred), corresponding to a translational failure mechanism which mainly involves the calcarenites but which also affects the underlying marls. Moreover, in the case of both the $0^{\circ}$ and $50^{\circ}$ incidence angles, the northern slope of the valley is affected by superficial failures (i.e. rockfalls, wedge failure strongly controlled by the joint sets) which involve the calcarenites. These findings are in very good agreement with the field observations collected after the occurrence of 11 May 2011 earthquake (Alfaro et al., 2012). Note that in the case of $60^{\circ}$ and $70^{\circ}$ incidence angles, no important instabilities occur apart from superficial failures which involve the calcarenites; in particular, in the case of a $70^{\circ}$ incidence angle, there are no failures involving the southern slope of the valley (where the rockslide actually occurred).

According to the here obtained results, the failure scenario which best represents what actually occurred is an incidence angle lower than $50^{\circ}$. For larger incidence angles, no relevant landslides are triggered (except for rockfall of wedge rockslides), whereas for normal incidence angles,

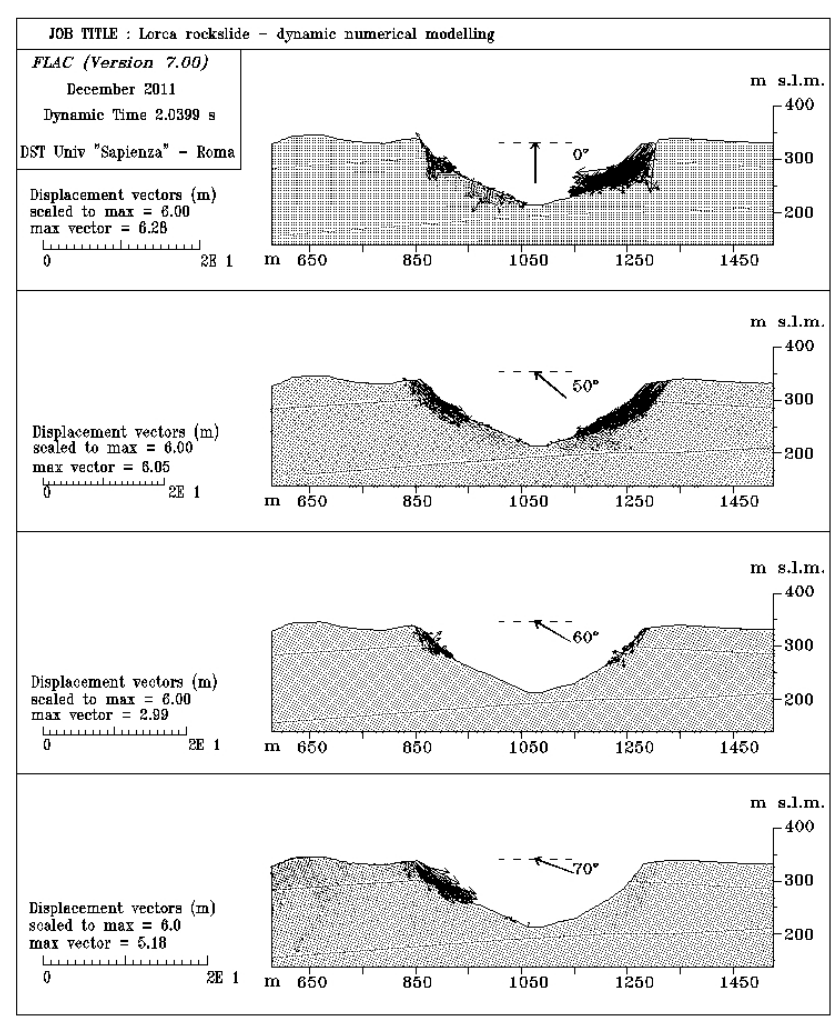

Fig. 8. Total displacements resulting by the FLAC dynamic numerical modeling after the seismic wave propagation at various incidence angles.

more than actually occurred are predicted to occur on both valley slopes.

A "parametric analysis" was also performed to test the dependence of the results on the values of the mechanical properties. The experimental variation of the strength parameters values reported in Table 2 was assumed plus the variation of the values attributed to the joint angle in the range effective dip - apparent dip, according to data reported in Table 1. Because negligible differences were observed among the results obtained by such a parametric analysis, it is possible to conclude that the choice of the parameter values within the assumed experimental ranges does not significantly affect the abovementioned solutions or the related considerations of the interaction between the seismic waves and the valley slopes. 


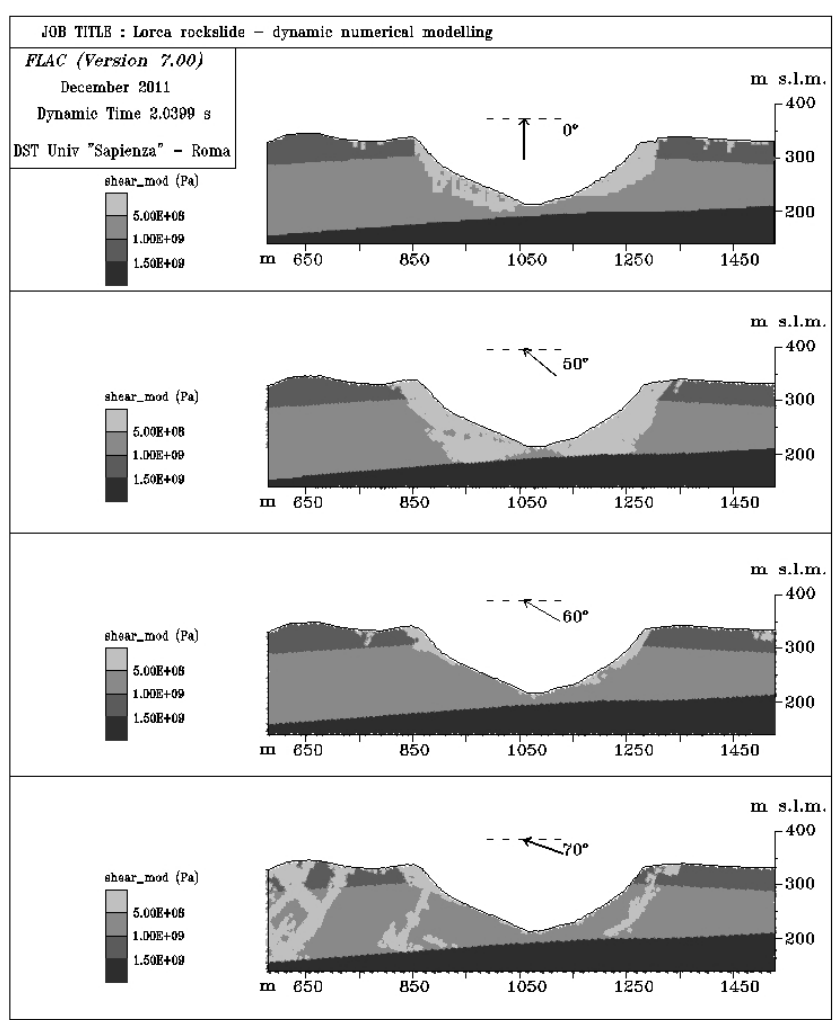

Fig. 9. Contour plot of the shear modulus values calculated from the FLAC dynamic numerical modeling using seismic wave propagation at various incidence angles.

\section{Discussion}

The interaction of seismic waves with slopes is a fundamental topic of study for estimating stronger constraints on provisional scenarios of seismically-induced landslide movements. This topic involves various scientific fields, such as engineering geology, geophysics, seismology, thus necessitating a multidisciplinary approach. Numerical modeling can estimate the criteria for analyzing the abovementioned interaction, but a reliable validation of outputs and results requires correlation with available case studies. Seismic records obtained during strong motion, plus specific geophysical techniques devoted to characterizing both the in situ dynamic properties of soils and the local seismic response, offer strong support during such validation.

In recent years, many landslide movements have been correlated with recorded ground motions and their occurrence have been analyzed in relation to seismic input properties. Based on this approach, some far-field landslide reactivations were explained as being due to seismic amplification owing to both the pre-existing landslide mass and geological setting (Bozzano et al., 2008, 2011b; Delgado et al., 2011).

However, these events could be expected based on a deterministic approach; that is, performing parametric numerical studies validated by analyzing previous events.

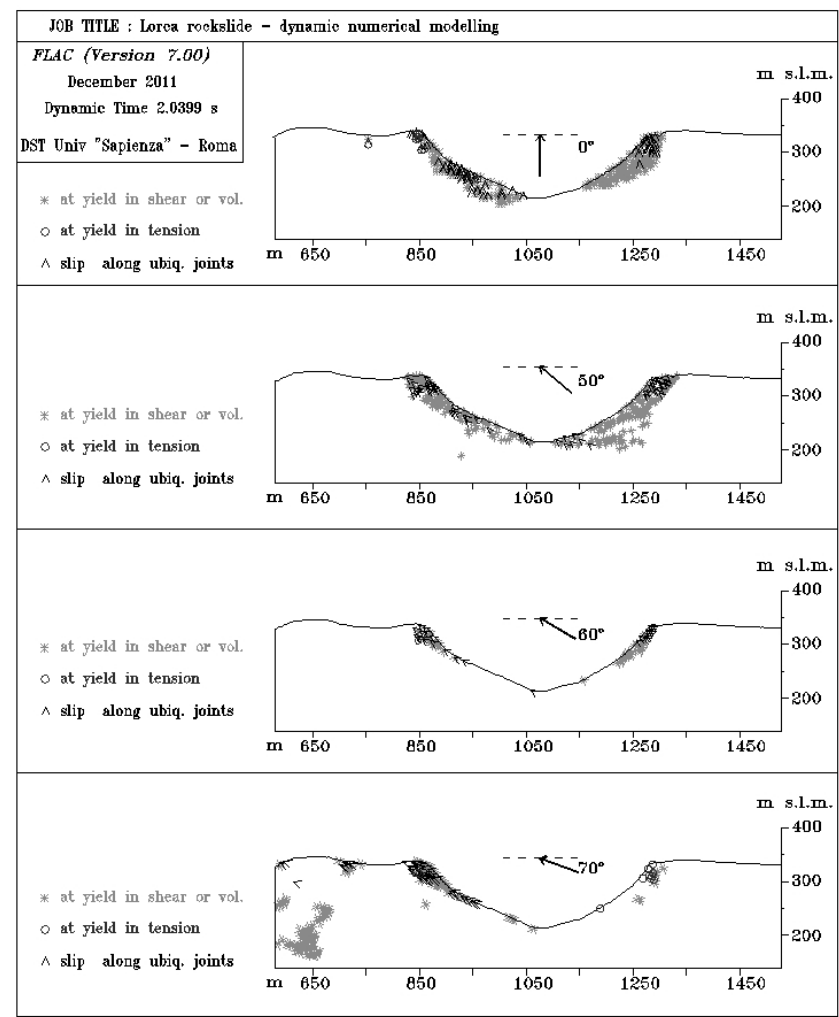

Fig. 10. Plasticity conditions resulting from the FLAC dynamic numerical modeling using seismic wave propagation at various incidence angles.

The same statistical approaches make it possible to estimate the epicentral distances at which to expect seismicallyinduced landslides. These distances can be used to define circular areas within which landslide events are expected for each. However, in each case, the analysis can be performed only by considering the outputs of parametric studies which take into account the interaction between seismic waves and slope, but not the angle of incidence of seismic waves, because such angle is close to $0^{\circ}$ (far-field conditions) and consequently do not represent a variable in the possible study. On the contrary, if near-field conditions are considered, both the angle of incidence and the direction of the seismic waves must be considered because the local seismic amplification effects can be significant.

The case study presented here shows the relevance of such features in providing a reliable scenario of a seismicallyinduced landslide trigger. In fact, an analysis of the recorded rockslide after the 11 May 2011 Lorca earthquake indicates that only in cases of high angle incidence is the a landslide expected along the southern slope of the valley; in contrast, for low angles of incidence, relevant slope instabilities occur along the northern slope of the valley. These findings are very well constrained by the available accelerometric records of the earthquake in near-field (obtained by the Spanish Strong 
Ground Motion Network), which make it possible to derive a specific waveform for the local seismic ground motion at "Rambla de los diecisiete ojos", i.e. for the landslide triggering input. To this aim, a spectral attenuation was performed, starting from the available accelerometric signals.

The seismic amplification related to the opened joint orientation, which is expected to be polarized normally to the joint direction (Burjanek et al., 2012), cannot be invoked to justify the triggering of the slope instability occurred at "Rambla de los diecisiete ojos". This is because the measured joint sets are angulated with respect to the cliffs (i.e. along the calcarenite outcrops) corresponding to both slopes of the valley. Moreover, because the joint orientation within the calcarenites is approximately the same on both slopes of the valley, the related seismic amplification alone could not explain the rockslide trigger that occurred only on the southern slope.

Consequently, two different scenarios of seismicallyinduced ground failure can be depicted for the same valley as well as for a same earthquake, if a different direction of the seismic wave front is assumed. Moreover, the direction and the related angle of incidence of the seismic waves can be regarded as mainly dependent on the location and the attitude of the seismogenetic fault as well as from the depth of the fault rupture.

The findings discussed here also highlight that for earthquake landslide triggering in the near-field, the angle of incidence of the seismic waves plays a role similar to the wellknown topographic effect (Ashford et al., 1997; Ashford and Sitar, 1997; Alfaro et al., 2012). Thus, some local conditions related to the geological setting (such as the undercut below the calcarenites cliff along the southern slope of the valley) can increase the local slope instability, making the slope more prone to an earthquake trigger.

Since the presented case study corresponds to a specific "first generation" landslide event (according to Hutchinson, 1988), i.e. occurred on an un-sheared slope, it is not possible to generalize the obtained results in terms of expected near-field ground effects due to an earthquake. Nevertheless, these results encourage collecting other case studies and performing more exhaustive parametric analyses, which should be performed by considering pre-existing landslide masses to provide more general criteria for the assessment of susceptibility to earthquake triggering in the near-field.

The present study does not give the possibility to predict future locations of "first generation" landslides but it demonstrates the relevance of the specific interaction of the seismic waves with the slopes in near-field conditions and, in particular, the relevance of the incidence angle. In this sense, it seems necessary to perform site-specific slope stability models, capable of taking into account the aforementioned interaction, for predicting more reliable scenarios of landslide triggering.

\section{Conclusions}

A large rockslide occurred close to Lorca, Spain, during the 11 May 2011 mainshock $\left(M_{\mathrm{w}}=5.1\right)$. The rockslide affected jointed rock masses consisting of calcarenites and marls. Despite the symmetrical shape and a similar geological setting along both slopes of the valley, only the southern slope of the valley was disturbed by a relevant earthquake-induced landslide.

The numerical modeling presented here, supported by geomechanical measurements and in situ geophysical investigations, demonstrated that the angle of incidence of the seismic waves plays a fundamental role in controlling the location of the landslide along the southern slope of the valley. Moreover, the most realistic triggering scenario of the rockslide corresponds to an angle of incidence in the range $0^{\circ}-$ $50^{\circ}$ by assuming a southern direction of the seismic waves and the same dynamic and geomechanical properties for the involved rock masses.

The results obtained highlight that the interaction between seismic wave direction and slope aspect cannot be neglected when considering the susceptibility of a location for earthquake-triggered landslides in near field conditions, i.e. where seismically-induced landslide events can be generally expected based on statistical and empirical approaches.

In general, the angle of incidence of the seismic waves can be regarded as responsible for landslides triggered by earthquakes. This is in addition to the well-known topographic effects and more specific local features related to rock mass jointing and the geological setting of the slope.

Considering this, more extensive parametric studies should be performed to investigate the effects due to the angle of incidence of seismic waves with respect to the following: (i) slope geometries, (ii) geological setting of the slopes, and (iii) pre-existing landslide masses.

Acknowledgements. The study is part of research activities carried out in the frame of the bilateral agreement between the Department of Earth Sciences, University of Rome "Sapienza" and the Department of Earth Sciences, University of Alicante. The Strong Ground Motion Network of Spain (IGN) kindly provided the accelerometric data used in this study. This work was partially funded by research groups VIGROB-53 and VIGROB-184 (Universidad de Alicante) and by the projects tec2008-06764-c02-02 and CGL2011-30153-c02-02. Pedro Jáuregui, Juan Luis Soler and Lucien Macone (Universidad de Alicante) helped during field works.

Edited by: T. Glade

Reviewed by: two anonymous referees 


\section{References}

Alfaro, P., Delgado, J., Garcia-Tortosa, F. J., Lenti, L., Lopez. J. A., Lopez-Casado, C., and Martino, S.: Widespread landslides induced by the Mw 5.1 earthquake of 11 May 2011 in Lorca, SE Spain, Eng. Geol., 137-138, 40-52, 2012.

Ashford, S. A. and Sitar, N.: Analysis of topographic amplification of inclined shear waves in a steep coastal bluff, Bull. Seism. Soc. Am., 87, 692-700, 1997.

Ashford, S. A., Sitar, N., Lysmer, J., and Deng, N.: Topographic effects on the seismic response of steep slopes, Bull. Seism. Soc. Am., 87, 701-709, 1997.

Athanasopoulos, G. A., Pelekis, P. C., and Leonidou, E. A.: Effects of surface topography on seismic ground response in the Egion (Greece) 15 June 1995 earthquake, Soil Dynam. Earthq. Eng., 18, 135-149, 1999.

Bakavoli, M. K. and Hagshenhas, E.: Experimental and numerical study of topographic site effect on a hill near Tehran, Proc. Fifth International Conference of Recent Advances in Geotechnical Earthquake Engineering and Soil Dynamics, 24-29 May, S. Diego, California, 1-9, 2010.

Barton, N. R. and Bandis, S. C.: Review of predictive capabilites of JRC-JCS model in engineering practice, in: Rock Joints, Proc. Int. Symp. on Rock Joints, Loen, Norway, edited by: Barton, N. and Stephansson. O., Rotterdam, Balkema, 603-610, 1990.

Bird, J. F. and Bommer, J. J.: Earthquake losses due to ground failure, Eng. Geol., 75, 147-179, 2004.

Bordoni, P., Di Giulio, G., Haines, A. J., Milana, G., Rovelli, A., and Ruso, S.: Issues in choosing the references to use for spectral ratios from observations and modeling at Cavola landslide in northern Italy, Bull. Seism. Soc. Am, 100, 1578-1613, 2010.

Bouckovalas, G. D. and Papadimitriou, A. G.: Numerical evaluation of slope topography effects on seismic ground motion, Soil Dynam. Earthq. Eng., 25, 547-558, 2005.

Bourdeau, C. and Havenith, H. B.: Site effects modeling applied to the slope affected by the Suusamyr earthquake (Kyrgyzstan, 1992), Eng. Geol., 97, 126-145, 2008.

Bousquet, J. C.: Quaternary strike-slip faults in southern Spain, Tectonophysics, 52, 277-286, 1979.

Bozzano, F., Lenti, L., Martino, S., Paciello, A., and Scarascia Mugnozza, G.: Self-excitation process due to local seismic amplification responsible for the 31st October 2002 reactivation of the Salcito landslide (Italy), J. Geophys. Res., 113, B10312, doi:10.1029/2007JB005309, 2008.

Bozzano, F., Lenti, L., Martino, S., Montagna, A., and Paciello, A.: Earthquake triggering of landslides in highly jointed rock masses: Reconstruction of the 1783 Scilla rock avalanche (Italy), Geomorphology, 129, 294-308, 2011a.

Bozzano, F., Lenti, L., Martino, S., Paciello, A., and Scarascia Mugnozza, G.: Evidences of landslide earthquake triggering due to self-excitation process, Int. J. Earth Sci., 100, 861-879, doi:10.1007/s00531-010-0514-5, 2011b.

Bray, J. D. and Rathje, E. M.: Earthquake-induced displacements of solid-waste landfills, J. Geotech. Geoenvir. Eng. ASCE, 124, 242-253, 1998.

Burjánek, J., Moore, J. R., Yugsi Molina, F. X., and Fäh, D.: Instrumental evidence of normal mode rock slope vibration, Geophys. J. Int., 188, 559-569, 2012.

Cabañas, L., Carreño, E., Izquierdo, A., Martínez-Solares, J. M., Capote, R., Martínez-Díaz, J., Benito, B., Gaspar, J., Rivas,
A., García-Mayordomo, J., Pérez, R., Rodríguez-Pascua, M. A., and Murphy-Corella, P.: Informe del sismo de Lorca del 11 de Mayo de 2011, Instituto Geográfico Nacional, available at: http://www.ign.es/ign/resources/sismologia/www/lorca/ Lorcainfo2011.pdf (last access: 1 February 2012), 2011.

Cetin, K. O., Isik, N., and Unutmaz, B.: Seismically induced landslide at Degirmendere Nose, Izmit Bay during Kocaeli (Izmit)Turkey earthquake, Soil Dynam. Earthq. Eng., 24, 189-197, 2004.

Chigira, M., Wu, X., Inokuchi, T., and Wang, G.: Landslides induced by the 2008 Wenchuan earthquake, Sichuan, China, Geomorphology, 118, 225-238, 2010.

Crawford, A. M. and Curran, J. H.: The influence of shear velocity on the frictional resistance of rock discontinuities, Int. J. Rock Mech. Min. Sci. Geomech. Abstr., 18, 505- 515, 1981.

De Larouzière, F. D., Bolze, J., Bordet, P., Hernández, J., Montenat, C., and Ott d'Estevou, P.: The Betic segment of the lithospheric Transalboran Shear Zone during the Late Miocene, Tectonophysics, 152, 41-52, 1988.

Del Gaudio, V. and Wasowski, J.: Advances and problems in understanding the seismic response of potentially unstable slopes, Eng. Geol., 122, 73-83, 2010.

Delgado, J., Garrido, J., López-Casado, C., Martino, S., and Peláez, J. A: On far field occurrence of seismically induced landslides, Eng. Geol., 123, 204-213, doi:10.1016/j.enggeo.2011.08.002, 2011.

Fukuoka, H., Sassa, K., and Scarascia Mugnozza, G.: Distribution of landslides triggered by the 1995 Hyogo-Ken Nanbu earthquake, J. Phys. Earth, 45, 83-90, 1997.

Gallipoli, M., Lapenna, V., Lorenzo, P., Mucciarelli, M., Perrone, A., Piscitelli, S., and Sdao, F.: Comparison of geological and geophysical prospecting techniques in the study of a landslide in southern Italy, European J. Env. Eng. Geophys, 4, 117-128, 2000.

Geli, L., Bard, P. Y., and Jullien, B.: The effect of topography on earthquake ground motion: a review and new results, Bull. Seism. Soc. Am., 78, 42-63, 1988.

Harp, E. L. and Jibson, R. W.: Anomalous concentrations of seismically triggered rock falls in Pacoima Canyon: are they caused by highly susceptible slopes or local amplification of seismic shaking?, Bull. Seism. Soc. Am., 92, 3180-3189, 2002.

Havenith, H. B., Jongmans, D., Faccioli, E., Abdrakhmatov, K., and Bard, P. Y.: Site effect analysis around the seismically induced Ananevo rockslide, Kyrgyzstan, Bull. Seism. Soc. Am., 92, 3190-3209, 2002.

Havenith, H.-B., Strom, A., Jongmans, D., Abdrakhmatov, A., Delvaux, D., and Tréfois, P.: Seismic triggering of landslides, Part A: Field evidence from the Northern Tien Shan, Nat. Hazards Earth Syst. Sci., 3, 135-149, doi:10.5194/nhess-3-135-2003, 2003a.

Havenith, H. B., Vanini, M., Jongmans, D., and Faccioli, E.: Initiation of earthquake-induced slope failure: influence of topographical and other site specific amplification effects, J. Seismol., 7, 397-412, 2003b.

Hoek, E., Carranza-Torres, C., and Corkum, B.: Hoek-Brown failure criterion - 2002 Edn., Proc. NARMS-TAC Conference, Toronto, 2002, 1, 267-273, 2002.

Hungr, O., Evans, S. G., Bovis, M. J., and Hutchinson, J. N.: A review of the classification of landslides of the flow type, Env. Eng. Geosci., 7, 221-238, 2001. 
Hutchinson, J. N.: Mechanism producing large displacements in landslides on pre-existing shears, Mem. Soc. Geol. China, 9, 175-200, 1987.

Hutchinson, J. N.: General report: morphological and geotechnical parameters of landslides in relation to geology and hydrogeology, Proc 5th Int Symp on Landslides, Lausanne, Switzerland, Balkema, Rotterdam, 3-36, 1988.

ISRM: Suggested methods for the quantitative description of discontinuities in rock masses, Int. J. Rock Mech. Min. Sci., 15, 319-368, 1978.

ITASCA: FLAC 7.0 - User manual, Licence number 213-0390127-30821 (Sapienza - University of Rome, Earth Science Department), 2011.

Kamalian, M., Sohrabi-Bidar, A., Razmkhah, A., Taghavi, A., and Rahmani, I.: Considerations on seismic microzonation in areas with two-dimensional hills, J. Earth Syst. Sci., 117, 783-796, 2008.

Keefer, D. K.: Landslides caused by earthquakes, Geol. Soc. Am. Bull., 95, 406-421, 1984.

Kuhlemeyer, R. L. and Lysmer, J.: Finite element method accuracy for wave propagation problems, J. Soil Mech. Found Div. ASCE, 99, 421-427, 1973.

Lenti, L. and Martino, S.: The interaction of seismic waves with step-like slopes and its influence on landslide movements, Eng. Geol., 126, 19-36, 2011.

Louie, J.: Faster, Better: Shear Wave Velocity to 100 meters Depth from Refraction Microtremor Arrays, Bull. Seism. Soc. Am., 91, 347-364, 2001.

Lovati, S., Bakavoli, M., Massa, M., Ferretti, G., Pacor, F., Paolucci, R., Haghshenas, E., and Kamalian, M.: Estimation of topographical effects at Narni ridge (Central Italy): comparison between experimental results and numerical modeling, Bull. Earthq. Eng., 9, 1987-2005, doi:10.1007/s10518-011-9315-x, 2011.

Maffei, A., Martino, S., and Prestininzi, A.: From the geological to the numerical model in the analysis of gravity-induced slope deformations: an example from Central Apennines (Italy), Eng. Geol., 78, 215-236, 2005.

Marinos, V., Marinos, P., and Hoek, E.: The Geological strength index: applications and limitations, B. Eng. Geol. Environ., 64, 55-65, 2005.

Martino, S. and Scarascia Mugnozza, G.: The role of the seismic trigger in the Calitri landslide (Italy): historical reconstruction and dynamic analysis, Soil Dynam. Earthq. Eng., 25, 933-950, 2005.

Méric, O., Garambois, S., Malet, J. P., Cadet, H., Guéguen, P., and Jongmans, D.: Seismic noise-based methods for soft-rock landslide characterization, Bull. Soc. Géol. Fr., 178, 137-148, 2007.

Montenat, C., Ott d'Estevou, P., and Coppier, G.: Les bassins néogènes entre Alicante et Cartagena, in: Les bassins néogènes du domaine bétique oriental (Espagne), Doc. et Trav., IGAL, 1213, 1990.

Moore, J. R., Gischig, V., Burjánek, J., Loew S., and Fäh, D.: Site effects in unstable rock slopes: dynamic behaviour of the Randa instability (Switzerland), Bull. Seism. Soc. Am., 101, 3110-3116, 2011.
Nguyen, K. V. and Gatmiri, B.: Evaluation of seismic ground motion induced by topographic irregularities, Soil Dynam. Earthq. Eng., 27, 183-188, 2007.

Optim L.L.C.: SeisOpt ReMi for Windows, Optim Software and Data Services, UNR-MS-174, 1664 N. Virginia St., Reno, Nevada, 2003.

Papadimitriou, A. G. and Chaloulos, Y.: Aggravation of the peak seismic acceleration in the vicinity of $2 \mathrm{D}$ hills, canyons and slopes, Proc. Fifth International Conference of Recent Advances in Geotechnical Earthquake Engineering and Soil Dynamics, 2429 May, S. Diego, California, 1-12, 2010.

Prestininzi, A. and Romeo, R.: Earthquake-induced ground failures in Italy, Eng. Geol., 58, 387-397, 2000.

Rodriguez, C. E., Bommer, J. J., and Chandler, R. J.: Earthquakeinduced landslides: 1980-1997, Soil Dynam. Earthq. Eng., 18, 325-346, 1999.

Romeo, R.: Seismically induced landslide displacements: a predictive model, Eng. Geol., 58, 337-351, 2000.

Sabetta, F. and Pugliese, A.: Attenuation of the peak horizonthal acceleration and velocity from italian strong-motion records, BSSA, 77, 1491-1511, 1987.

Sanchez-Sesma, F. J. and Rosenblueth, E.: Ground motion at canyons of arbitrary shape under incident SH waves, Earthq. Eng. Struct. Dynam., 7, 441-450, 1979.

Sassa, K.: Prediction of earthquake induced landslides, in: Landslides, edited by: Senneset, K., Balkema, Rotterdam, 115-132, 1996.

Semblat, J. F. and Pecker, A.: Waves and vibrations in soils: earthquake, traffic, shocks, construction works, IUSS Press, ISBN: 8861980309, 499 pp., 2009.

Sepulveda, S. A., Murphy, W., Jibson, R. W., and Petley, D. N.: Seismically induced rock slope failures resulting from topographic amplification of strong ground motions: The case of $\mathrm{Pa}-$ coima Canyon, California, Eng. Geol., 80, 336-348, 2005a.

Sepulveda, S. A., Murphy, W., and Petley, D. N.: Topographic controls on coseismic rock slides during the 1999 Chi-Chi earthquake, Taiwan, Q. J. Eng. Geol. Hydrogeol., 38, 189-196, 2005 b.

Silva, P. G., Goy, J. L., Somoza, L., Zazo, C., and Bardají, T.: Landscape response to strike-slip faulting linked to collissional settings: Quaternary tectonics and basin formation in the Eastern Betics, Southeast Spain, Tectonophysics, 224, 289-303, 1993.

Wasowski, J. and Del Gaudio, V.: Evaluating seismically induced mass movement hazard in Caramanico Terme (Italy), Eng. Geol., 58, 291-311, 2000.

Wrobel, F. and Michalzik, D.: Facies successions in the preevaporitic Late Miocene of the Lorca Basin, SE Spain, Sediment. Geol., 127, 171-191, 1999.

Zaslavsky, Y. and Shapira, A.: Experimental study of topographic amplification using the Israel seismic network, J. Earthq. Eng., 4, 43-65, 2000.

Zhai, E., Roth, W., Dawson, E., and Davis, C.: Seismic deformation analysis of an earth dam - a comparison study between equivalent-linear and nonlinear effective-stress approaches, 13th World Conference on Earthquake Engineering Vancouver, BC, Canada 1-6 August 2004, Paper No. 3298, 2004.

Zienkiewicz, O.: The Finite Element Method, McGraw-Hill (London), 785 pp., 2005. 